\title{
Faktor-faktor yang mempengaruhi kompetensi petani dalam melakukan usahatani ikan air tawar di kecamatan Polanharjo kabupaten Klaten
}

\author{
The factors that affect the competence of farmers in conducting freshwater fish farming in \\ Polanharjo sub-district, Klaten district \\ Erlin Yusliana ${ }^{1 *}$, Sapja Anantanyu ${ }^{1}$, Eksa Rusdiyana ${ }^{1}$ \\ ${ }^{1}$ Program Studi Penyuluhan dan Komunikasi Pertanian, Universitas Sebelas Maret, Surakarta, Jawa Tengah \\ *Email korespondensi: eksarusdiyana@staff.uns.ac.id
}

Informasi artikel: Dikirim: 22/05/2020 Ditinjau: $30 / 05 / 2020$ Disetujui: 01/09/2020

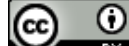

Copyright (c) 2020 Erlin Yusliana, Sapja Anantanyu, Eksa Rusdiyana

\begin{abstract}
Ability is an individual capacity to do various tasks in a profession or activity. This study aimed at scrutinizing the internal factors (age, education level, farming experience, and cosmopolitan level) and external factors (the roles of agricultural extension officers, the roles of the heads of farmer groups, local government support, and access to mass media) of the farmers in practicing freshwater fish farming in Polanharjo Sub-district, Klaten Regency, and the correlation between both the internal and external factors and farmers' ability in practicing freshwater fish farming in Polanharjo Sub-district, Klaten Regency. This research applied a qualitative method with a survey technique. The research location was determined by considering that Polanharjo Sub-district in Klaten Regency Further, Nganjat Village, and Janti. Samples were taken using proportional random sampling, involving 60 respondents. Data were analyzed using Spearman's rank correlation test with IBM SPSS 20.0. The results of this study include three major points. The farmers' age and education levels were considered high, while their farming practice experience and cosmopolitan levels were low. The role of agricultural extension officers and the support of the local government was low, while the role of heads of farmer groups and access to mass media was very low. The roles of agricultural extension officers and the heads of farmer groups had a highly significant relationship with the farmers' ability to practice freshwater fish farming. Nevertheless, Farmers' age, education level, farming experience, and cosmopolitan level, local government support, and access to mass media did not show any noteworthy relationship with farmers' ability to practice freshwater fish farming.
\end{abstract}

Keywords: ability, factor, farmer,freshwater fish

ABSTRAK: Kemampuan merupakan kapasitas seseorang individu untuk melakukan berbagai tugas dalam sebuah pekerjaan atau kegiatan. Penelitian ini bertujuan untuk menganalisis: (1) faktor internal (umur, tingkat pendidikan, pengalaman usahatani, tingkat kosmopolitan) dan faktor eksternal (peran penyuluh pertanian, peran ketua kelompok tani, dukungan pemerintah daerah dan akses media massa) petani dalam melakukan usahatani ikan air tawar di Kecamatan Polanharjo Kabupaten Klaten. (2) hubungan faktor internal dan faktor eksternal petani dengan kompetensi petani dalam melakukan usahatani ikan ai tawar di Kecamatan Polanharjo Kabupaten Klaten. Metode dasar penelitian adalah kuantitatif dengan teknik survei. Lokasi penelitian ditentukan secara sengaja yaitu Desa Nganjat dan Desa Janti Kecamatan Polanharjo, Kabupaten Klaten. Pengambilan sampel menggunakan teknik propotional rondom sampling terdiri dari 60 responden petani ikan air tawar. Analisis data menggunakan uji Rank Spearmandengan program IBM SPSS 20. Hasil penelitian menunjukkan bahwa: (1) umur petani termasuk dalam kategori tinggi, tingkat pendidikan termasuk dalam kategori tinggi, pengalaman berusahatani dalam kategori rendah, tingkat kosmopolitan dalam kategori rendah, peran penyuluh pertanian dalam kategori rendah, peran ketua kelompok tani termasuk dalam kategori sangat rendah, dukungan 
pemerintah daerah termasuk dalam kategori rendah, akses media massa termasuk dalam kategori sangat rendah, (2) terdapat hubungan yang sangat signifikan antara peran penyuluh pertanian, peran ketua kelompok tani dengan kemampuan petani dalam melakukan usahatani ikan air tawar, namun tidak terdapat hubungan yang signifikan antara umur, tingkat pendidikan, pengalaman berusahatani, tingkat kosmopolitan, dukungan pemerintah daerah, akses media massa dengan kemampuan petani dalam melakukan usahatani ikan air tawar.

Kata kunci: faktor, ikan air tawar, kemampuan, petani, usahatani

Sitasi: Yusliana, E., Anantanyu, S., \& Rusdiyana, E. (2020). Faktor-faktor yang mempengaruhi kompetensi petani dalam melakukan usahatani ikan air tawar di kecamatan Polanharjo kabupaten Klaten. AGROMIX, 11(2), 202-217. https://doi.org/10.35891/agx.v11i2.2022

\section{PENDAHULUAN}

Subsektor perikanan memiliki potensi untuk meningkatkan perekonomian nasional, baik pada perikanan laut maupun perikanan air tawar. Perikanan laut maupun darat memiliki keanekaragaman jenis ikan sehingga memungkinkan untuk dilakukan pengembangan budidaya ikan yang menguntungkan. Menurut Sekretaris Jendral KKP (2018) pertumbuhan bruto (PDB) perikanan terus mengalami pertumbuhan positif pada tahun 2018, pada triwulan III nilai PDB perikanan mencapai 59.984,3 triliun, angka tersebut meningkat 3.71\% jika dibandingkan dengan PDB pada tahun 2017 dalam periode yang sama hanya mencapai 57.838,0 triliun. Potensi perikanan budidaya air tawar berperan besar dalam meningkatkan kesejahteraan petani nelayan (Febriyanti, 2013). Salah satu usahatani ikan air tawar Kabupaten Klaten terletak di Kecamatan Polanharjo yang memiliki kontribusi produksi hasil perikanan tahun 2019 sebanyak 12.344,219 ton (Badan Pusat Statistik, 2019).

Pemberdayaan masyarakat melalui pengembangan sumber daya perikanan dapat meliputi pengintegrasian sumber daya terkait seperti sumber daya air, keragaman ikan, hasil pertanian dan sumber daya manusia (Pujiasmanto dkk., 2015). Dalam pemberdayaan masyarakat tersebut perlu dipahami bahwa petani sangat dipengaruhi oleh faktor internal dan eksternal. Faktor-faktor yang dapat menjadi penghambat pemberdayaan dan partisipasi serta menjadi penyebab permasalahan masyarakat lapisan bawah di tingkat komunitas tidak berdaya menghadapi lapisan yang lebih kuat perlu dicermati dan diperhatikan dengan baik. Salah satunya adalah faktor internal. Faktor internal berasal dari dalam diri atau karakteristik individu yang mempengaruhi pemberdayaan dan partisipasi di tingkat komunitas. Faktor internal yang berhubungan dapat berupa umur, tingkat pendidikan, jumlah beban keluarga, jumlah pendapatan, pengalaman kelompok (Fitriadi dkk., 2018). Faktor eksternal adalah faktorfaktor yang menghambat pemberdayaan dan partisipasi serta menjadi penyebab permasalahan masyarakat di tingkat komunitas menjadi tidak berdaya. Faktor eksternal merupakan faktor dari luar yang bisa mendorong maupun menghambat partisipasi antara lain peran stakeholder dan adanya kesempatan. Selain itu, juga bisa berupa kurang 
inovatif dalam melaksanakan pelatihan sehingga masyarakat bosan dan enggan berpartisipasi (Nabila \& Yuniningsih, 2016). Usia merupakan salah satu faktor yang mempengaruhi cara bekerja dan pola pikir petani dalam kegiatan pertanian (Hartono \& Rohaeni, 2014), semakin tinggi tingkat pendidikan seseorang, semakin berkembang pola berpikirnya sehingga dapat dengan mudah mengambil keputusan (Mulieng dkk., 2018).

Pengalaman berusahatani merupakan satu hal yang sangat mempengaruhi dari kemampuan petani dalam mencapai keberhasilan mengelola usahatani. Pengalaman dalam berusahatani mempengaruhi keberhasilan usahatani, karena petani yang memiliki pengalaman yang cukup lama akan cenderung memiliki kemampuan dan keterampilan apabila dibandingkan dengan petani yang kurang berpengalaman (Agussabti \& Makmur, 2017). Meskipun pendidikan rendah, akan tetapi pengalaman berusahatani yang dimiliki dapat membantu petani mencapai keberhasilan, karena semakin tinggi pengalaman dari tingkat keterampilan, kemahiran, dan keahlian yang dimiliki petani maka semakin besar hasil pencapaian produksi pertanian yang ingin dicapai. Tingkat kosmopolitan juga akan berpengaruh terhadap keberhasilan usahatani. Semakin tinggi tingkat kekosmopolitan maka akan semakin tinggi tingkat penerapan teknologinya, semakin sering responden dalam mencari informasi yang berkaitan dengan kegiatan usahatani berpengaruh besar dalam penerapan teknologi pada usahataninya (Suharyani \& Oktariana, 2018).

Faktor eksternal yang sangat berpengaruh pada pemberdayaan petani bisa berasal dari faktor penyuluh, ketua kelompok tani, peran sektor swasta maupun pemerintah, serta media massa (Ruhimat, 2017). (Huda \& Harijati, 2016) menyatakan bahwa penyuluhan bertujuan untuk memberdayakan masyarakat, meningkatkan kesejahteraan secara mandiri, serta membangun masyarakat madani. Penyuluhan adalah untuk menghasilkan perubahan perilaku dan tindakan yang menguntungkan. Pembentukan kelompok tani bertujuan agar petani lebih mudah dikoordinir sehingga kelompok tani menurut (Prasetyo, Safitri, \& Hidayat, 2019) membutuhkan adanya pemimpin (ketua kelompok) untuk mengatur dan mengordinasikan kelompok tani. Meski demikian dalam akses informasi untuk meningkatkan kemandirian dalam berusaha tani, petani saat ini mulai menggunakan berbagai bentuk media massa seperti televisi, radio, surat kabar, majalah, dan lain-lain yang mempunyai pengaruh besar dalam pembentukan pengetahuan dan kemampuan petani (Azwar, 2013).

Dalam berusaha tani, masing-masing petani memiliki kemampuan yang berbedabeda. Zakaria dan Nurasa (2013) menyatakan bahwa kemampuan petani berkaitan dengan situasi lingkungan serta keadaan yang melekat 
pada dirinya. Petani berperan sebagai manajer, juru tani dan manusia biasa yang hidup dalam masyarakat. Petani sebagai manajer Berhadapan dengan berbagai alternatif yang harus diputuskan mana yang harus dipilih untuk diusahakan, menentukan cara produksi, cara pembelian sarana produksi, menghadapi persoalan tentang biaya, mengusahakan permodalan dan sebagainya. Untuk itu, diperlukan keterampilan, pendidikan dan pengalaman yang akan berpengaruh dalam proses pengambilan keputusan. Petani sebagai juru tani harus dapat mengatur, melaksanakan dan mengawasi kegiatan usahataninya, baik secara teknis maupun ekonomis. Di samping itu, tersedia sarana produksi dan peralatan akan menunjang keberhasilan petani sebagi juru tani. Petani sebagai anggota masyarakat yang hidup dalam suatu ikatan keluarga akan selalu berusaha memenuhi kebutuhan keluarganya (Kuheba, Dumais, \& Pangemanan, 2016).

Kemampuan usahatani ikan air tawar merupakan kombinasi dari pengetahuan, sikap dan keterampilan yang ada dalam diri petani. Maka dari hal tersebut perlu dilakukan suatu penelitian yang berkaitan dengan faktor-faktor yang mempengaruhi kemampuan petani dalam melakukan usahatani ikan air tawar. Berdasarkan latar belakang tersebut, tujuan penelitian ini adalah mengkaji: (1) faktor internal (umur, tingkat pendidikan, pengalaman usahatani, tingkat kosmopolitan) dan faktor eksternal (peran penyuluh pertanian, peran ketua kelompok tani, dukungan pemerintah daerah dan akses media massa) dalam melakukan usahatani ikan air tawar di Kecamatan Polanharjo Kabupaten Klaten. (2) hubungan umur, pendidikan, pengalaman usahatani, tingkat kosmopolitan dan peran penyuluh pertanian, peran ketua kelompok tani, dukungan pemerintah daerah, akses media massa dengan kemampuan petani dalam melakukan usahatani budidaya ikan air tawar di Kecamatan Polanharjo Kabupaten Klaten.

\section{METODE}

Penelitian ini menggunakan metode penelitian kuantitatif. Pemilihan Kecamatan Polanharjo Kabupaten Klaten dilakukan secara sengaja (purposive) karena secara geografis memiliki sumber air yang mendukung untuk diterapkan usahatani ikan air tawar. Populasi penelitian ini adalah anggota kelompok tani yang terlibat dalam usahatani ikan air tawar yaitu petani ikan di Desa Nganjat dan Desa Janti. Sampel penelitian berjumlah 60 orang yang diambil secara proportional random sampling.

Sumber data terdiri dari sumber data primer dan sumber data sekunder, data primer diperoleh secara langsung dari petani, sedangkan data sekunder diperoleh dari catatan administrasi kelompok tani, pustaka maupun sumber lainnya. Pengumpulan data diperoleh melalui observasi, wawancara, dokumentasi, dan studi pustaka. Pengujian 
instrumen kuesioner penelitian menggunakan uji validitas dan uji reliabilitas dengan menggunakan bantuan program IBM SPSS 20.0. Uji validitas dengan menggunakan korelasi pearson diperoleh 123 item valid dari 130 jumlah item murni. Uji reliabilitas dengan cronbach alpha dengan nilai 0,946 yang berarti kuisioner memiliki tingkat reliabilitas sangat tinggi (baik). Analisis data untuk mengetahui kemampuan petani (kemampuan teknik, manajerial, sosial), faktor internal (umur, tingkat pendidikan, pengalaman berusahatani, tingkat kosmopolitan), faktor eksternal (peran penyuluh pertanian, peran ketua kelompok tani, dukungan lembaga luar, akses media massa) petani dalam melakukan usahatani ikan air tawar menggunakan rumus lebar interval dengan variabel $\mathrm{X}$ dikategorikan dalam 4 skor (sangat tinggi, tinggi, rendah, sangat rendah) dan 3 skor (tinggi, sedang, rendah) untuk variabel Y.

Analisis data untuk mengetahui hubungan antara faktor internal (umur, tingkat pendidikan, pengalaman berusahatani, tingkat kosmopolitan), faktor eksternal (peran penyuluh pertanian, peran ketua kelompok tani, dukungan lembaga luar, akses media massa) dengan kemampuan petani dalam melakukan usahatani ikan air tawar menggunakan analisis korelasi Rank Spearman $\left(r_{s}\right)$. Untuk menguji tingkat signifikansi hubungan perbandingan nilai Sig (2-tailed) dengan tingkat kepercayaan $95 \%$ dengan tingkat kesalahan yang ditoleransi $(\alpha=0,05)$ kriteria pengambilan keputusan yakni nilai Sig (2-tailed) $\leq(\alpha=0,05)$, maka Ho ditolak, artinya terdapat hubungan yang signifikan antara faktor internal petani dan faktor eksternal petani dengan kemampuan petani dalam melakukan usahatani budidaya ikan air tawar. jika Sig 2-tailed $>(\alpha=0,05)$, maka Ho diterima, artinya tidak terdapat hubungan yang signifikan antara faktor internal petani dan faktor eksternal petani dengan kemampuan petani dalam melakukan usahatani budidaya ikan di Kecamatan Polanharjo Kabupaten klaten.

\section{HASIL DAN PEMBAHASAN}

Usahatani ikan air tawar di kecamatan Polanharjo Klaten

Kecamatan Polanharjo merupakan salah satu kecamatan yang berada di Kabupaten Klaten yang memiliki kekayaan akan sumber daya alam khususnya sumber daya air yang bersumber dari Umbul Ponggok. Keberadaan kolam seluas $227.001 \mathrm{~m}^{2}$ dimanfaatkan oleh masyarakat untuk pengembangan usahatani ikan air tawar, termasuk memanfaatkan tanah kurang subur untuk usaha perikanan. Oleh Kementerian Kelautan dan Perikanan (KKP), Polanharjo dikelompokkan dalam kategori wilayah minapolitan II (kategori budidaya ikan air tawar seperti lele dan nila) dan minapolitan III (kategori budidaya ikan hias seperti ikan cupang dan ikan arwana). Usahatani ikan air 
tawar oleh masyarakat sudah dimulai sejak tahun 1995 dan dikenal sebagai desa unggul ikan nila. Produksi ikan terbesar dihasilkan oleh 2 desa utama yaitu Desa Nganjat dengan produksi ikan 2.086,669 ton/tahun dan desa Desa Janti dengan produksi 2.216,135 ton/tahun.

Petani ikan Desa Nganjat dan Desa Janti memiliki kemampuan dasar dalam menentukan benih ikan, jenis pakan, serta perawatan ikan, termasuk menentukan mitra usaha seperti supplier benih, pakan, obat dan tengkulak/pasar. Namun demikian sebagian besar kolam ikan merupakan kolam yang dimiliki oleh pihak desa dan disewa pertahun/3 bulan sesuai dengan kemampuan petani. Pendapatan yang diperoleh petani ikan mencapai Rp. 10.000 .000 - Rp. 15.000 .000 tergantung dari jumlah kolam yang disewa serta jumlah benih ikan yang dikembangkan. Usaha tani ikan dengan model seperti ini dinilai lebih menguntungkan dibandingkan dengan usaha tani padi. Aktivitas usaha tani ikan di Desa Nganjat dan Desa Janti disajikan dalam Tabel 1. berikut.

Tabel 1. Aktivitas usahatani ikan air tawar di kecamatan Polanharjo, Klaten

\begin{tabular}{|c|c|c|c|}
\hline No & Aspek & Desa Nganjat & Desa Janti \\
\hline 1. & Benih ikan & $\begin{array}{l}\text { Sebagian besar membeli di } \\
\text { tengkulak, sebagian kecil } \\
\text { melakukan pembibitan sendiri } \\
\text { selama 1-2 bulan }\end{array}$ & $\begin{array}{l}\text { Sebagian besar membeli di } \\
\text { tengkulak, Sebagian kecil melakukan } \\
\text { pembibitan sendiri selama } 1-2 \text { bulan } \\
\text { atau dengan ukuran yang sesuai } \\
\text { keinginan }\end{array}$ \\
\hline 2. & Pembesaran & $\begin{array}{l}\text { Benih ikan dibeli kemudian } \\
\text { dipindahkan di kolam pembesaran, } \\
\text { umur dan jenis ikan harus sama }\end{array}$ & $\begin{array}{l}\text { Benih ikan dibeli kemudian } \\
\text { dipindahkan di kolam pembesaran, } \\
\text { umur dan jenis ikan harus sama }\end{array}$ \\
\hline 3. & Pakan & $\begin{array}{l}\text { Membeli di pabrik pakan dan } \\
\text { saprodi perikanan }\end{array}$ & $\begin{array}{l}\text { Membeli di pabrik pakan dan saprodi } \\
\text { perikanan }\end{array}$ \\
\hline 4. & Aspek lain & $\begin{array}{l}\text { Benih ikan berasal dari luar kota } \\
\text { bahkan propinsi, hasil panen ikan } \\
\text { langsung dijual ke tengkulak sesuai } \\
\text { permintaan dari tengkulak. Panen } \\
\text { ikan tidak harus pada umur } 5-6 \\
\text { bulan, apabila } 3-4 \text { bulan ukuran } \\
\text { ikan sudah cukup bisa langsung } \\
\text { dijual ke tengkulak. }\end{array}$ & $\begin{array}{l}\text { Benih ikan berasal dari luar kota } \\
\text { bahkan propinsi. Ikan dijual di } \\
\text { tengkulak langsung tanpa perantara. } \\
\text { Petani banyak memanfaatkan kolam } \\
\text { menjadi tempat pemancingan } \\
\text { sekaligus warung makan, apabila } \\
\text { terdapat beberapa ikan yang tidak } \\
\text { laku dijual, maka digunakan untuk } \\
\text { bahan baku usaha warung } \\
\text { makannya. }\end{array}$ \\
\hline
\end{tabular}

Sumber : Analisis data, 2020

Desa Nganjat memiliki satu kelompok tani baik ketika memberi pakan ikan, sehingga ikan namun kondisinya kurang aktif semua permasalahan ikan senantiasa dikarenakan petani-petani di Desa Nganjat didiskusikan di kolam. Sedangkan di Desa Janti sudah sering bertemu dengan sesama anggota terdapat 3 kelompok tani yaitu Mina Makmur, 
Wahyu Tirta dan Mina Sari Mulya, namun hanya 1 kelompok tani yang aktif dan rutin melakukan pertemuan 1 bulan sekali (membahas terkait simpan pinjam, arisan serta permasalahan sekitar usahatani ikan). Kedua kelompok tani lainnya tidak berjalan lancar dikarenakan terjadi permasalahan di mana kelompok tani tidak mampu membayar kembali bunga yang dipinjam dari bank setempat.

Responden dalam penelitian ini merupakan petani ikan di Desa Nganjat dan Desa Janti yang berjumlah 60 orang yang dipilih secara proporsional random sampling. Ratarata umur responden berada pada usia produktif $(51,7 \%)$, dengan tingkat pendidikan cukup baik yaitu lulusan SMA. Pengalaman responden dalam usaha tani berada pada kategori rendah (45\%) karena selama ini pengalaman diperoleh melalui pelatihan dan saling sharing dengan petani lain. Sedangkan kegiatan penyuluhan tentang perikanan sangat jarang diberikan. Petani selama ini sangat banyak belajar dari pengalaman di lapangan, apabila terdapat permasalahan di lahan maka petani cukup bertanya pada petani lainnya di sekitar kolam. Termasuk semua kebutuhan perikanan cukup mudah diperoleh di lingkungan desa setempat, tidak perlu mencari ke luar desa. Hal inilah yang menyebabkan tingkat kosmopolitan petani ikan juga rendah.

Uji Validitas kuisioner menunjukkan bahwa dari 130 item pertanyaan, terdapat 123 item pertanyaan yang valid. Berdasarkan uji reliabilitas yang telah dilakukan diperoleh hasil nilai cronbach alpha keseluruhan item yaitu 0,946 yang berarti reliabilitas sangat tinggi (baik) sehingga instrumen penelitian dapat dikatakan reliabel. Hasil uji validitas instrumen penelitian disajikan dalam tabel 2 . berikut.

Tabel 2. Hasil uji validitas

\begin{tabular}{|c|c|c|c|}
\hline No & Variabel & Item murni & Item Valid \\
\hline 1. & Umur & 1 & 1 \\
\hline 2. & Tingkat pendidikan & 1 & 1 \\
\hline 3. & Pengalaman Usahatani & 1 & 1 \\
\hline 4. & Tingkat Kosmopolitan & 1 & 1 \\
\hline 5. & Peran Penyuluh pertanian & 15 & 15 \\
\hline 6. & Peran Ketua kelompok tani & 15 & 12 \\
\hline 7. & Dukungan Lembaga luar & 7 & 7 \\
\hline 8. & Akses Media Massa & 28 & 28 \\
\hline 9. & Kemampuan Teknis & 26 & 24 \\
\hline 10. & Kemampuan Manajerial & 16 & 14 \\
\hline 11. & Kemampuan Sosial & 19 & 19 \\
\hline & Jumlah & 130 & 123 \\
\hline
\end{tabular}

Sumber: Analisis data, 2020 
Kemampuan petani dalam melakukan pada petani pembudidaya ikan dipengaruhi

usahatani ikan air tawar

Kapasitas secara umum diartikan sebagai kemampuan yang dimiliki oleh seseorang internal akan mempengaruhi kemampuan (Fatchiya, 2010). Tingkat kapasitas yang ada seseorang dalam menjalankan pekerjaannya.

Tabel 3. Kemampuan petani dalam melakukan usahatani ikan air tawar di kecamatan Polanharjo

\begin{tabular}{llccc}
\hline No & \multicolumn{1}{c}{ Kemampuan } & Capaian & Persentase (\%) & Kategori \\
\hline 1. & Kemampuan Teknis & 51,87 & $53,3 \%$ & Sedang \\
2. & Kemampuan Manajerial & 34,68 & $73,3 \%$ & Sedang \\
3. & Kemampuan Sosial & 36,51 & $31,7 \%$ & Sedang \\
\hline
\end{tabular}

Sumber: Analisis data, 2020

Kemampuan teknis petani dalam Hubungan faktor internal dan faktor eksternal melakukan usahatani ikan berada dalam kategori sedang. Artinya dalam bidang teknis petani cukup baik dalam melakukan budidaya ikan berdasarkan standar operasional yang sesuai dengan varietas ikan. Kemampuan manajerial petani dalam hal ini juga dalam kategori sedang, artinya petani cukup mampu mengelola usahatani ikan termasuk merencanakan biaya yang dibutuhkan sehingga mendapatkan keuntungan. Kemampuan sosial petani termasuk dalam kategori sedang, yang berarti petani cukup mampu menjalin hubungan kerjasama dengan komunitasnya. dengan kemampuan petani dalam melakukan usahatani ikan air tawar di kecamatan

\section{Polanharjo kabupaten Klaten}

\section{a. Faktor internal}

Dalam menjalankan berbagai macam kegiatan usahatani tidak terlepas dari adanya karakteristik individu petani sendiri. Menurut Setiono (2016) karakteristik individu merupakan suatu proses psikologi yang mempengaruhi individu dalam memperoleh, mengkonsumsi serta menerima barang dan jasa serta pengalaman. Karakteristik individu merupakan faktor internal (interpersonal) yang menggerakkan dan mempengaruhi perilaku individu. Setiap manusia memiliki karakteristik individu yang berbeda antara satu dengan yang lainnya. Karakteristik individu tersebut meliputi faktor internal yakni umur, tingkat pendidikan, pengalaman berusahatani dan tingkat kosmopolitan. 
Tabel 4. Faktor internal yang berhubungan dengan kemampuan petani dalam melakukan usahatani ikan air tawar di Kecamatan Polanharjo Kabupaten Klaten

\begin{tabular}{llcc}
\hline \multicolumn{1}{c}{ Faktor Internal } & Kategori & Jumlah (orang) & Persentase (\%) \\
\hline Umur & Produktif & 31 & 51,7 \\
Tingkat Pendidikan & Tinggi & 29 & 48,3 \\
Pengalaman Berusahatani & Rendah & 27 & 45,0 \\
Tingkat Kosmopolitan & Rendah & 40 & 66,7 \\
\hline
\end{tabular}

Sumber : Analisis Data, 2020

Umur petani di Kecamatan Polanharjo Kabupaten Klaten didominasi oleh petani dengan umur 46-55 tahun. Petani yang memiliki umur produktif memiliki kemampuan dalam melakukan aktivitas kegiatan yang berat, kuat dan mampu mengembangkan inovasiinovasi baru ke dalam kegiatannya sehingga kegiatan usahataninya meningkat. Tingkat pendidikan petani ikan di Kecamatan Polanharjo berada dalam kategori tinggi. Sedangkan pengalaman berusahatani berdasarkan lamanya petani dalam melakukan kegiatan usahataninya, mayoritas dalam kategori rendah. Usahatani ikan air tawar di Kecamatan Polanharjo sudah dimulai tahun 1995, namun petani baru tertarik untuk mengembangkan usahatani ikan air tawar pada tahun 2003. Petani merasakan bahwa usaha tani ikan lebih menguntungkan dibandingkan dengan usahatani padi, keuntungan yang didapat bisa 10 kali lipat dari usahatani padi tersebut.

Pada tingkat kosmopolitan, dengan didasarkan pada intensitas petani bepergian keluar desa atau kota untuk mencari informasi usaha tani ikan berada dalam kategori rendah karena kebutuhan sarana produksi usahatani ikan tersedia di sekitar desa. Petani keluar desa hanya untuk urusan-urusan yang mendesak dan keperluan lain di luar urusan perikanan. Petani lebih baik bertanya ke sesama petani dari pada keluar desa atau kota untuk mencari informasi mengenai usahatani ikan.

\section{b. Faktor eksternal}

Proses perubahan perilaku individu dapat diperoleh dari belajar dan dukungan dari lingkungan atau pengaruh-pengaruh dari lembaga luar yang kuat. Faktor eksternal ini meliputi peran penyuluh pertanian, peran ketua kelompok tani, dukungan dari lembaga luar serta akses media massa.

Tabel 5. Faktor eksternal yang berhubungan dengan kemampuan petani dalam melakukan usahatani ikan air tawar di kecamatan Polanahrjo Kabupaten Klaten

\begin{tabular}{llcc}
\hline \multicolumn{1}{c}{ Faktor Eksternal } & Kategori & Jumlah (orang) & Persentase (\%) \\
\hline Peran Penyuluh Pertanian & Rendah & 31 & 51,7 \\
Peran Ketua Kelompok Tani & Sangat Rendah & 29 & 48,3 \\
Dukungan Lembaga Luar & Rendah & 27 & 45,0 \\
Akses Media Massa & Sangat Rendah & 40 & 66,7 \\
\hline
\end{tabular}

Sumber : Analisis data, 2020 
Peran penyuluh perikanan di Kecamatan memfasilitasi kolam ikan yang disewakan

Polanharjo termasuk dalam kategori rendah, kepada petani selama 3-6 bulan (sesuai dikarenakan penyuluh perikanan di Kecamatan perjanjian), sedangkan fasilitas kredit usaha Polanharjo masih baru sehingga petani merasa tergantung dari kelompok tani apakah akan pengalaman mereka masih lebih baik dari mengakses atau tidak.

pengalaman penyuluh. Petani lebih sering

Upaya meningkatkan kemampuan petani sharing dengan sesama petani ikan yang juga dilaksanakan dengan memanfaatkan dianggap lebih mampu memberikan solusi dari permasalahan yang dihadapi. Peran ketua media massa untuk mendapatkan informasikelompok tani juga termasuk dalam kategori sangat rendah, dikarenakan ketua kelompok tani jarang melakukan koordinasi serta pengawasan terhadap kelompok taninya.

Dukungan dari berbagai pihak dibutuhkan untuk pelaksanaan meningkatkan kemampuan petani dalam melaksanakan kegiatan informasi seputar perikanan. Akan tetapi petani kurang memanfaatkan ketersediaan informasi dari media massa. Petani merasa ketersediaan informasi perikanan dari media massa baik televisi, majalah/koran/brosur/leaflet, radio sangat kurang sekali, sehingga petani lebih baik bertanya ke sesama petani ikan yang lain tentang informasi-informasi seputar perikanan. usahataninya. Menurut Damanik (2015) Petani menggunakan smartphone hanya dukungan kebijakan sangat diperlukan dalam sebatas untuk menghubungi agen benih ikan, mempersiapkan tenaga yang profesional, tengkulak, maupun agen pakan saja.

penyediaan dana untuk pembinaan, Hasil analisis hubungan faktor internal dan penyuluhan, penyediaan kredit, sarana dan prasarana, yang dibutuhkan dalam pembangunan pertanian perikanan. Dukungan dari lembaga luar dalam pengembangan usaha tani ikan di Kecamatan Polanharjo termasuk dalam kategori rendah, partisipasi pemerintah daerah dalam penyelenggaraan sosialisasi, pelatihan, serta penyuluhan dinilai petani masih kurang. Pemerintah daerah hanya faktor eksternal dengan kemampuan petani dalam melakukan usahatani ikan air tawar di kecamatan Polanharjo Kabupaten Klaten

Hasil analisis hubungan faktor internal dan faktor eksternal dengan kemampuan petani dalam melakukan usahatani ikan air tawar di Kecamatan Polanharjo Kabupaten Klaten dengan korelasi Rank Spearman $\left(\mathrm{r}_{\mathrm{s}}\right)$ terlihat dalam Tabel 6 berikut. 
Tabel 6. Uji signifikansi hubungan antara faktor internal, faktor eksternal dengan kemampuan petani dalam melakukan usahatani ikan air tawar di kecamatan Polanharjo Kabupaten Klaten

\begin{tabular}{llll}
\hline $\begin{array}{c}\text { Faktor-faktor yang berhubungan } \\
\text { dengan kemampuan petani dalam } \\
\text { melakukan usahatani ikan air } \\
\text { tawar (X) }\end{array}$ & \multicolumn{3}{c}{ Kemampuan petani dalam melakukan usahatani ikan air } \\
\cline { 2 - 4 } tawar (Y)
\end{tabular}

Sumber : Analisis data, 2020

Berdasarkan Tabel 6, faktor umur tidak berhubungan signifikan dengan kemampuan petani dalam melakukan usahatani ikan air tawar. Perbedaan umur tidak membedakan kompetensi petani ikan yang tua dengan muda petani dalam usaha tani ikan. Hal ini berbeda dengan Ilmi dan Henniwati (2019) yang menyatakan bahwa bertambahnya umur seseorang akan berpengaruh terhadap bertambahnya pengetahuan akan tetapi pada umur-umur tertentu atau menjelang usia lanjut maupun penerimaan atau peningkatan sesuatu pengetahuan akan berkurang. Tingkat pendidikan juga tidak berhubungan signifikan dengan kemampuan petani dalam melakukan usahatani ikan air tawar. Pengetahuan petani berasal dari pengalaman dan sharing dengan sesama petani. Sehingga petani dengan berpendidikan tinggi maupun rendah mempunyai kesempatan yang sama untuk mengembangkan usahataninya. Hal ini sesuai dengan pendapat Simamora dan Luik (2019) yang menyatakan bahwa pendidikan dengan kompetensi tidak memiliki hubungan nyata.

Tingkat pendidikan petani tidak mencerminkan hubungan dengan kompetensi teknis. Faktor pengalaman berusahatani tidak berhubungan signifikan dengan kemampuan petani dalam melakukan usahatani ikan. Baik petani yang sudah memiliki pengalaman lama atau baru memiliki kompetensi usaha tani ikan yang tidak berbeda. Usahatani ikan yang dilakukan mayoritas masih tradisional dan belum banyak melakukan diversifikasi baik jenis ikan, jenis pakan, maupun sistem pemasarannyan. Hal ini tidak sesuai dengan pernyataan Simamora dan Luik (2019) yang menyatakan bahwa pengalaman petani dalam berusaha tani memiliki hubungan nyata dengan kompetensi teknis. Petani yang sudah lama bertani akan lebih mudah untuk menerapkan inovasi daripada petani pemula, hal ini dikarenakan pengalaman yang lebih banyak sehingga sudah dapat membuat perbandingan 
dalam mengambil keputusan (Krisnawati dkk., 2013).

Pada faktor kosmopolitan juga tidak berhubungan signifikan dengan kemampuan petani. Petani jarang melakukan kunjungan atau bepergian keluar desa untuk mencari informasi seputar perikanan, dikarenakan petani merasa lebih baik bertanya dengan petani sekitarnya yang memiliki keterampilan dan pengetahuan yang baik terkait perikanan. Hal tersebut tidak sesuai dengan pernyataan Suharyani dan Oktariana (2018) bahwa frekuensi keluar desa menggambarkan intensitas dalam berinteraksi dengan lingkungan luar desa yang akan mempengaruhi kompetensi petani dalam usaha tani.

Penyuluh pertanian memiliki hubungan sangat signifikan dengan kemampuan petani dalam melakukan usahatani ikan di Kecamatan Polanharjo Kabupaten Klaten. Hal ini menunjukkan bahwa semakin tinggi upaya yang dilakukan penyuluh pertanian maka akan semakin baik juga kemampuan petani dalam melakukan usahatani ikan air tawar. Penyuluh pertanian memiliki kontribusi yang sangat besar dalam meningkatkan kemampuan kinerja petani. Kemampuan penyuluh dalam melaksanakan kegiatan penyuluhan sangat diperlukan dalam proses pengembangan kapasitas. Hal ini senada dengan pendapat Fatchiya (2010) yang menyebutkan bahwa untuk meningkatkan kapasitas petani dibutuhkan dukungan pendampingan dari penyuluh. Meskipun realitanya penyuluh perikanan di Polanharjo jarang memberikan penyuluhan maupun pelatihan pada petani ikan.

Peran ketua kelompok tani adalah semua bentuk kegiatan ketua kelompok tani sebagai koordinator, inspirator, dan motivator untuk semua anggota kelompok tani yang dipimpinnya (Ruhimat, 2017). Peran ketua kelompok tani memiliki hubungan yang signifikan dengan kemampuan petani dalam melakukan usahatani ikan. Hal ini menunjukkan bahwa semakin baik upaya yang dilakukan ketua kelompok tani, maka semakin baik untuk peningkatan kemampuan petani dalam melakukan usahatani ikan. Ketua kelompok tani menjadi tempat bertanya anggota kelompok tani terkait permasalahan seperti budidaya ikan, harga ikan, benih, kredit usah serta masalah perikanan lainnya. Sesuai dengan pendapat Ruhimat (2017) bahwa efektivitas ketua kelompok tani akan berpengaruh terhadap tingkat kapasitas anggota kelompok tani, tingkat dinamis dan tingkat partisipasi anggota tani sehingga secara tidak langsung akan berpengaruh terhadap kemampuan kelembagaan kelompok tani. Sayangnya peran ketua kelompok tani dalam pengembangan usaha tani ikan kurang berjalan dengan baik, minimnya ketua kelompok dalam mengkoordinasi pertemuan kelompok menyebabkan fungsi kelompok tani banyak yang kurang aktif. 
Dukungan lembaga luar tidak memiliki

hubungan signifikan dengan kemampuan petani dalam melakukan usahatani. Hal ini tidak sesuai dengan pendapat Ruhimat (2017), bahwa faktor yang berpengaruh dalam kapasitas kelembagaan kelompok tani yaitu dukungan pihak luar dari kelembagaan kelompok tani seperti dukungan swasta dan dukungan pemerintah daerah. Pada faktor akses media massa tidak memiliki hubungan signifikan dengan kemampuan petani dalam melakukan usahatani ikan. Petani menilai bahwa informasi yang tersedia di berbagai media massa kurang memadai dan repot untuk mengaksesnya sehingga petani tidak mengakses informasi dari media massa tersebut. Selama ini petani hanya mendapatkan informasi terkait perikanan dari petani lainnya seperti halnya terkait informasi harga benih ikan, harga pakan, harga rata-rata dari tengkulak. Petani hanya menggunakan handphone untuk mendapatkan informasi tersebut. Mengacu pada pendapat Puttileihalat (2011) berkaitan dengan ketersediaan informasi pada media massa, televisi, radio, surat kabar kurang menyediakan informasi yang menjadi kebutuhan petani.

Berdasarkan temuan pada Tabel 6 terdapat 2 faktor signifikan yang mempengaruhi kompetensi petani ikan di Kecamatan Polanharjo yaitu faktor penyuluh pertanian dan faktor ketua kelompok tani. Baik penyuluh pertanian maupun ketua kelompok tani dinilai kurang berperan oleh anggota

kelompok tani. Penyuluh pertanian masih baru sehingga petani merasa lebih pintar dari penyuluh perikanan, sementara ketua kelompok tani tidak menjalankan fungsinya sebagai koordinator petani dengan baik. Hal ini berimplikasi pada kurang aktifnya pertemuan kelompok, tidak terfasilitasinya kebutuhan anggota oleh kelompok. Petani merasa cukup dengan kebiasaan sharing dengan petani lainnya ketika terjadi permasalahan ataupun kendala. Penyuluh dan ketua kelompok tani tidak menjadi rujukan petani untuk menyelesaikan kendala usaha taninya. Terkait dengan permasalahan ini, sebaiknya petani mulai terbuka dengan penyuluh perikanan yang baru, penyuluh perlu diberikan kesempatan oleh petani untuk memperkenalkan diri dan menyampaikan program-programnya. Kondisi ini tidak bisa hanya dari satu sisi semata, sebaliknya penyuluh wajib berinisiatif melakukan koordinasi dengan petani dan ketua kelompok tani sehingga keberadaan ketua kelompok tani bisa diaktifkan dan aktivitas kelompok tani bisa aktif kembali. Dua tokoh sentral inilah yang sangat berperan meningkatkan kompetensi petani baik melalui kegiatan penyuluhan dan pelatihan maupun aktivitas kelompok tani.

\section{KESIMPULAN}

Analisis tingkat capaian kemampuan petani yang meliputi kemampuan manajerial, 
kemampuan sosial, dan kemampuan sosial dalam usahatani ikan termasuk dalam kategori sedang. Faktor internal petani dalam melakukan usahatani ikan meliputi: (a) umur petani dalam kategori produktif $(51,7 \%)$, (b) tingkat pendidikan petani mencapai pendidikan setingkat SMA sederajat atau dalam kategori tinggi $(48,3 \%)$, (c) pengalaman berusahatani termasuk dalam kategori rendah (45\%), dan (d) tingkat kosmopolitan termasuk dalam kategori rendah (66,7\%). Sedangkan faktor eksternal petani meliputi: (a) peran penyuluh pertanian dalam kategori rendah $(51,7 \%)$, (b) peran ketua kelompok tani dalam kategori sangat rendah $(48,3 \%)$, (c) dukungan lembaga luar termasuk dalam kategori rendah (45\%), dan (d) akses media massa termasuk dalam kategori sangat rendah $(66,7 \%)$. Faktor internal berupa umur, tingkat pendidikan, pengalaman berusahatani, tingkat kosmopolitan, dan faktor eksternal berupa dukungan lembaga luar dan akses media massa tidak berhubungan signifikan dengan kemampuan petani dalam melakukan usahatani ikan air tawar di Kecamatan Polanharjo Kabupaten Klaten.

Sedangkan faktor eksternal berupa peran penyuluh dan peran ketua kelompok tani memiliki peran signifikan dengan kompetensi petani dalam usaha tani ikan. Peran penyuluh dan peran ketua kelompok tani dinilai masih kurang oleh petani, sehingga baik penyuluh maupun ketua kelompok tani perlu meningkatkan peranannya dalam mendampingi petani dan kelompok tani. Penyuluh wajib berinisiatif melakukan komunikasi dengan petani (kelompok tani) untuk melaksanakan program kerjanya, sedangkan ketua kelompok tani wajib menjalankan roda organisasi kelompok tani dengan baik khususnya menjalankan fungsi koordinasi dan pertemuan anggota kelompok secara rutin. Baik penyuluh maupun ketua kelompok tani memiliki peran strategis meningkatkan kompetensi petani dalam bentuk menyelenggarakan kegiatan penyuluhan, pelatihan maupun menjadi referensi ketika petani memiliki masalah dalam usaha taninya.

\section{DAFTAR PUSTAKA}

Agussabti, A., \& Makmur, T. (2017). Analisis tingkat keberhasilan usahatani sayuran di kecamatan Permata kabupaten Bener Meriah. Jurnal Imiah Mahasiswa Pertanian Unsyiah, 2(3), 191-202. https://doi.org/10.17969/jimfp.v2i3.3748

Azwar, S. M. A. (2013). Sikap manusia teori dan pengukurannya (Ed. 2). Yogyakarta: Pustaka Pelajar.

Badan Pusat Statistik. (2019). Kecamatan polanharjo dalam angka. https://klatenkab.bps.go.Id/publication/2 017/09/20/fbbeecb52b9c0c6dccf436c7/k ecamatan-polanharjo-dalam-angka2019.html

Damanik, I. P. (2015). Faktor-faktor yang mempengaruhi dinamika kelompok dan hubungannya dengan kelas kemampuan kelompok tani di desa Pulokencana kabupaten Serang. Jurnal Penyuluhan, 9(1), 31-40. https://doi.org/10.25015/penyuluhan.v9i 1.9856

Fatchiya, A. (2010). Tingkat kapasitas pembudidaya ikan dalam mengelola 
usaha akuakultur secara berkelanjutan fish farmer capacity to manage of aquabusiness sustainability. Jurnal Penyuluhan, 6(1), 74-83. http://journal.ipb.ac.id/index.php/jupe/is sue/archive

Febriyanti, E. R. (2013). Kontribusi pengembangan kawasan minapolitan kampung lele terhadap pendapatan petani lele di desa tegalrejo sawit boyolali. Economics Development Analysis Journal, 2(4), 396-407. https://doi.org/10.15294/edaj.v2i4.3208

Fitriadi, M. Y. G., Sumardjo, S., \& Hamzah, H. (2018). Gaya kepemimpinan tokoh informal dan tingkat partisipasi masyarakat dalam program desa mandiri pangan. Jurnal Sains Komunikasi Dan Pengembangan Masyarakat [JSKPM], 2(4), 455. https://doi.org/10.29244/jskpm.2.4.455464

Hartono, B., \& Rohaeni E. S. (2014). Conntribution to income of traditional beef cattle farmer households in Tanah Laut Regency, South Kalimantan, Indonesia. Journal of Livestock Research For Rural Development, 26(8), 1-10.

Huda, N., \& Harijati, S. (2016). Peran penyuluh dalam pemberdayaan masyarakat pertanian perkotaan. Repository.Ut.Ac.Id, 205-222. Retrieved from https://scholar.google.co.id/scholar?hl=id \&as_sdt $=0 \% 2 \mathrm{C} 5 \& \mathrm{q}=$ Peran+Penyuluh+dal am+Pemberdayaan+Masyarakat+Pertania $\mathrm{n}+$ Perkotaan\&btnG =

IImi, T., \& Henniwati. (2019). Hubungan tingkat pengetahuan pasien terhadap tindakan swamedikasi pada masyarakat kelurahan Pojok kota Kediri. Java Health Journal, 6(1), 1-8. https://doi.org/10.1210/jhj.v6i1.275

Krisnawati, K., Purnaningsih, N., \& Asngari, P. (2017). Persepsi petani terhadap peranan penyuluh pertanian di desa Sidomulyo dan Muari, Distrik Oransbari, kabupaten Manokwari Selatan. Sosio Konsepsia, 2(3), 303-314.

https://doi.org/10.33007/ska.v2i3.783
Kuheba, J. A., Dumais, J. N. K., \& Pangemanan, P. A. (2016). Perbandingan pendapatan usahatani campuran berdasarkan pengelompokan jenis tanaman. Jurnal Agri-Sosioekonomi, 12(2A), 77. https://doi.org/10.35791/agrsosek.12.2a. 2016.12601

Mulieng, Z. F., Amanah, S., \& Asngari, P. S. (2018). Persepsi petani terhadap kompetensi penyuluh pertanian tanaman pangan di Kabupaten Aceh Utara. Jurnal Penyuluhan, 14(1), 159-174. https://doi.org/10.25015/penyuluhan.v1 4i1.17556

Nabila, A. R., \& Yuniningsih, T. (2016). Analisis partisipasi masyarakat dalam pengembangan Desa Wisata Kandri Kota Semarang. Journal of Public Policy and Management Review, 5(3), 1-20. https://doi.org/10.14710/jppmr.v5i3.125 42

Prasetyo, A., Safitri, R., \& Hidayat, K. (2019). Strategi komunikasi ketua dalam meningkatkan eksistensi kelompok (kasus di kelompok tani Sidodadi di desa Junrejo, kecamatan Junrejo kota Batu Jawa Timur). Jurnal Habitat, 30(1), 26-34. https://doi.org/10.21776/ub.habitat.2019 .030.1.4

Pujiasmanto, B., Sutopo, S., Aliyah, I., \& Mulyanto, M. (2015). Minapolitan untuk mendukung ketahanan dan keamanan pangan. Caraka Tani: Journal of Sustainable Agriculture, 30(2), 97. https://doi.org/10.20961/carakatani.v30i 2.11926

Puttileihalat, P. M. (2011). Hubungan karakteristik dengan keterdedahan media massa petani jambu mete (Kasus petani jambu mete di Desa Neumatang Kecamatan Wetar Kabupaten Maluku Barat Daya). Agrikan: Jurnal Ilmiah Agribisnis dan Perikanan, 4(2), 47. https://doi.org/10.29239/j.agrikan.4.2.47 $-51$

Ruhimat, I. S. (2017). Peningkatan kapasitas kelembagaan kelompok tani dalam pengembangan usahatani agroforestry: studi kasus di desa Cukangkawung, 
kecamatan Sodonghilir, kabupaten

Tasikmalaya, provinsi Jawa Barat. Jurnal

Penelitian Sosial dan Ekonomi Kehutanan,

14(1),

1-17.

https://doi.org/10.20886/jsek.2017.14.1.

1-17

Setiono, B. A. (2016). Pengaruh budaya organisasi, karakteristik individu, karakteristik pekerjaan terhadap kinerja karyawan PT. Pelindo III Surabaya. Jurnal Aplikasi Pelayaran dan Kepelabuhan, 6(2), 128-146.

http://dx.doi.org/10.30649/jurapk.v6i2.3

0

Simamora, T., \& Luik, R. (2019). Tingkat kompetensi teknis petani dalam berusahatani singkong (kasus kelompok Mekar Tani Desa Cibanteng Kecamatan Ciampea Kabupaten Bogor. Jurnal Agrimor, 4(4), 53-55. https://doi.org/10.32938/ag.v4i4.824

Suharyani, A., \& Oktoriana, S. (2018). Pengaruh tingkat imitasi dan kosmopolitan wanita tani terhadap keputusan pengelolaan usahatani. Jurnal Agrifo, 3(2), 1-10. https://doi.org/10.29103/ag.v3i2.1114

Zakaria, A. K., \& Nurasa, T. (2013). Strategi penggalangan petani untuk mendukung program peningkatan produksi padi berkelanjutan. Jurnal Analisis Kebijakan Pertanian, 11(2), 75-87. http://dx.doi.org /10.21082/akp.v11n2.2013.75-87 